\title{
Blalock-Taussig anastomosis in 126 patients with Fallot's tetralogy
}

\author{
J . M . REID, E. N. COLEM A N, R. S. B A R C L A Y, a nd \\ J. G. STE VENSON
}

University Department of Child Health and Department of Cardiology, Royal Hospital for Sick Children,
and the Cardio-Thoracic Unit, Mearnskirk Hospital, Glasgow

The long-term results of Blalock anastomosis in 126 patients (1954-71) for Fallot's tetralogy are presented. The operative mortality was $10 \%$ and the overall mortality $38 \%$. The 78 survivors were reviewed after periods of surveillance ranging from six months to 17 years. Complications were few.

It is concluded that although total correction as a primary procedure has become the treatment of choice in most, it may in some instances never be technically feasible because of extreme underdevelopment of the right ventricular outflow tract. In the very young with urgent symptoms and rapid deterioration total correction would be considered hazardous. In the infant a high operative mortality reflected the inadequate calibre of the vessels used in the shunt operation.

Blalock and Taussig (1945) introduced the first effective palliative prosedure for the relief of Fallot's tetralogy by anastomosing the right subclavian artery to the corresponding pulmonary artery. Subsequent palliative operations have either anastomosed the aorta to a pulmonary artery (Potts, Smith, and Gibson, 1946 ; Waterston, 1962) or aimed to relieve the right ventricular outflow tract obstruction (Brock, 1948, 1952).

During 17 years we have employed almost exclusively the Blalock-Taussig anastomosis for all patients over the age of 1 year with Fallot's tetralogy demanding urgent surgical intervention because of increasing disability. We present an assessment of the results of operation and of the subsequent progress of these patients.

\section{CLINICAL MATERIAL}

Between April 1954 and April 1971 a Blalock-Taussig shunt was created in 126 patients as a primary procedure for Fallot's tetralogy. Sixty-six patients were male and 60 female. The age at operation ranged from 6 weeks to 24 years; $68 \%$ (86) were under 3 years of age. The four patients aged 10 years and over occurred early in the series; had they presented in more recent years primary total correction would certainly have been performed by choice. All the patients were severely disabled, pronounced cyanosis and breathlessness being the commonest presenting symptoms, while in the most severely affected children cyanotic attacks accompanied in some instances by loss of consciousness were frequently reported. The survivors were reviewed finally in December 1971.

\section{RESULTS}

Deaths at operation (Table I) numbered $13(10 \%)$, eight of which occurred among the 20 patients under 1 year of age.

\section{T A B L E I}

126 PATIENTS WITH FALLOT'S TETRALOGY WHO UNDERWENT BLALOCK-TAUSSIG SHUNT

\begin{tabular}{l|c|c|c|c|c|c}
\hline & \multicolumn{5}{|c|}{ Age } \\
\cline { 2 - 7 } & $0-6 \mathrm{mth}$ & $7-11 \mathrm{mth}$ & $1-3 \mathrm{yr}$ & $4-10 \mathrm{yr}$ & $11-20 \mathrm{yr}$ & $>20 \mathrm{yr}$ \\
\hline $\begin{array}{c}\text { Number } \\
\text { Early } \\
\text { deaths }\end{array}$ & 12 & 16 & 58 & 36 & 3 & 1 \\
\hline
\end{tabular}

Early mortality $=13$ of $126(10 \cdot 3 \%)$ (under 1 year 8 deaths out of $28=28 \%)$. Late deaths 35 of $113(31 \%)$. Total mortality $=35+13=$ 48 out of $126=38 \%$

COMPLICATIONS AND LATER DEATHS All 113 patients who survived operation continued under outpatient supervision for periods ranging from eight months to 17 years. Eight patients developed major complications, namely cerebral abscess in five with two deaths, cerebral thrombosis in two, and bacterial meningitis in one. Bacterial endocarditis was not encountered. The two who survived a cerebral thrombosis had a permanent hemiparesis. 
T A B L E I I

35 LATE DEATHS IN 113 SURVIVORS ( $31 \%)$

\begin{tabular}{|c|c|c|c|c|c|c|c|}
\hline \multicolumn{3}{|c|}{ Related to Further Surgery } & \multirow{2}{*}{$\begin{array}{l}\text { Cerebral } \\
\text { Abscess }\end{array}$} & \multirow{2}{*}{$\begin{array}{l}\text { Cardiac } \\
\text { Failure }\end{array}$} & \multirow{2}{*}{$\begin{array}{l}\text { Unknown } \\
\text { (at home) }\end{array}$} & \multirow[b]{2}{*}{ Hepatitis } & (D) \\
\hline Total Correction & Waterston Shunt & $\begin{array}{l}\text { Pulmonary } \\
\text { Valvotomy }\end{array}$ & & & & & ڤ) \\
\hline 21 & 5 & 1 & 2 & 2 & 3 & 1 & \\
\hline
\end{tabular}

There were 35 late deaths giving a total mortality of $38 \%$. Twenty-seven of these deaths resulted from further surgical treatment, two from unexpected cardiac failure, and one from hepatitis; three occurred at home without a clearly identified cause and two were from cerebral abscess as already mentioned (Table II). The formidable mortality with which complete repair after a Blalock-Taussig anastomosis was initially associated declined sharply in later years.

Of the 113 survivors of the first operation, 54 had a total of 57 additional surgical procedures. These were pulmonary valvotomy or infundibulectomy in 15 , of whom three subsequently underwent total correction, a Waterston shunt in 13 infants or small children with unsatisfactory Blalock-Taussig shunts, and total correction in 29. The time interval between the Blalock-Taussig anastomosis and further surgical intervention was from two months to 14 years (mean 5.7 years). In only 10 patients was the second operation undertaken within three years of the first. Six of these were infants who underwent a Waterston anastomosis some months after an unsuccessful Blalock and of whom three died, emphasizing the desperate plight of those with

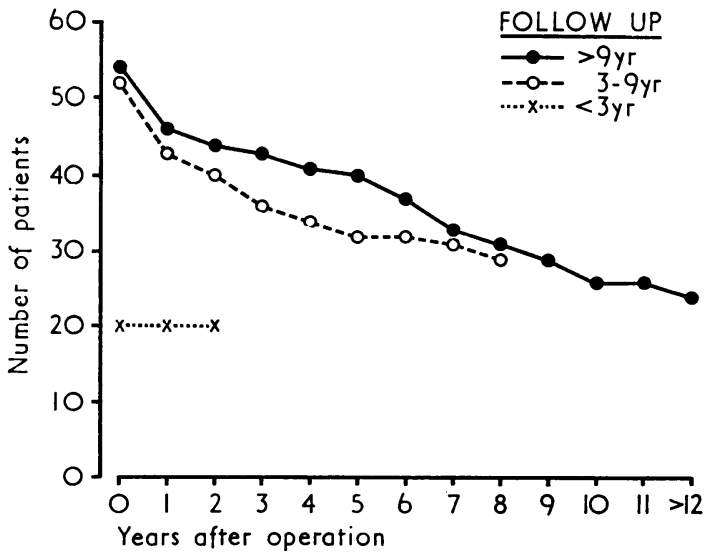

FIG. 1. Late results in three groups showing numbers alive at follow-up: $\bigcirc$ follow-up $>9$ years; $\bigcirc--\bigcirc$ followup 3-9 years; $\times---\times$ follow-up $<3$ years. a severely obstructed right ventricular outlet. The remainder (47) underwent further surgery at interto vals of three to 12 years after their shunt oper $\frac{\infty}{\omega}$ tion.

LONG-TERM FOLLOW-UP For the consideration of late results the original 126 patients were divided. into three groups (Fig. 1).

Group 1 This comprised 54 patients operated on more than nine years previously of whom sif died at operation, 24 died during follow-up, an\& 24 were still alive at review in December 1978 Thus $50 \%$ of those who survived operation were alive and well more than nine years after operw tion. Of these, 11 have had no further surgers while 13 had either pulmonary valvotomy or tota correction. Nine had survived for more than 1 years after operation.

Group 2 This comprised 52 patients operated of three to nine years previously among whom there were seven operative deaths and 11 late deaths leaving $34(75 \%$ of the survivors of operation alive and well.

Group 3 This comprised 20 patients operated on within the previous three years. All were alive and well.

\section{PRESENT STATUS OF SURVIVORS}

Of the original 126 patients, 78 (62\%) survived. Twenty-seven had undergone further surgicaP treatment (three patients each underwent twly further surgical procedures). A clinical assessmertw of those patients is outlined in Table III. Of the 51 who had had no further surgical treatment 40 had evidence of a functioning anastomosis anf showed no sign of deterioration. In 11 there hap been some deterioration; one patient had declined further surgical treatment, two were awaiting total correction, and eight were awaiting preoperes tive reassessment by cardiac catheterization Thirty-one patients underwent cardiac catheter zation and angiocardiography at varying intervals after their initial anastomosis ; in none was there evidence of pulmonary hypertension. 
T A B LE III

CLINICAL STATUS OF 78 SURVIVORS

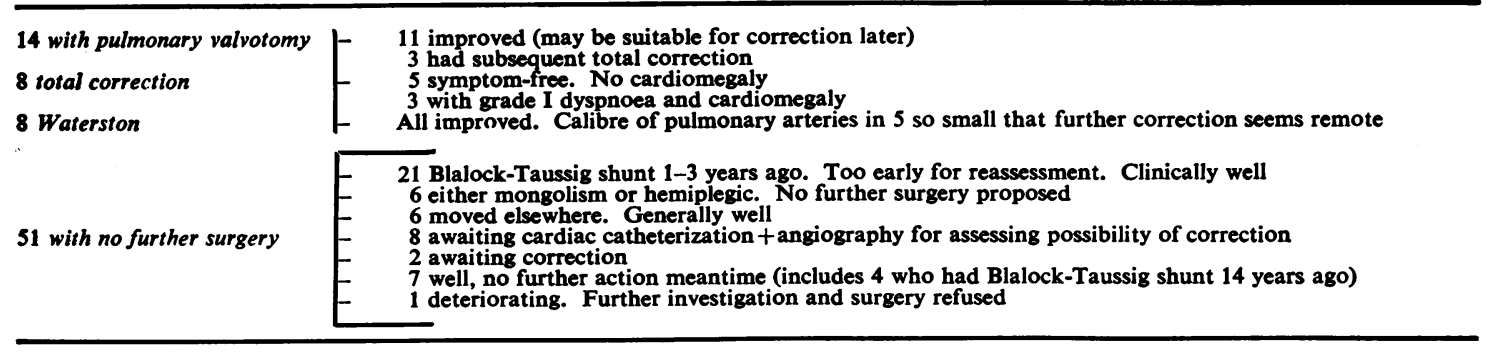

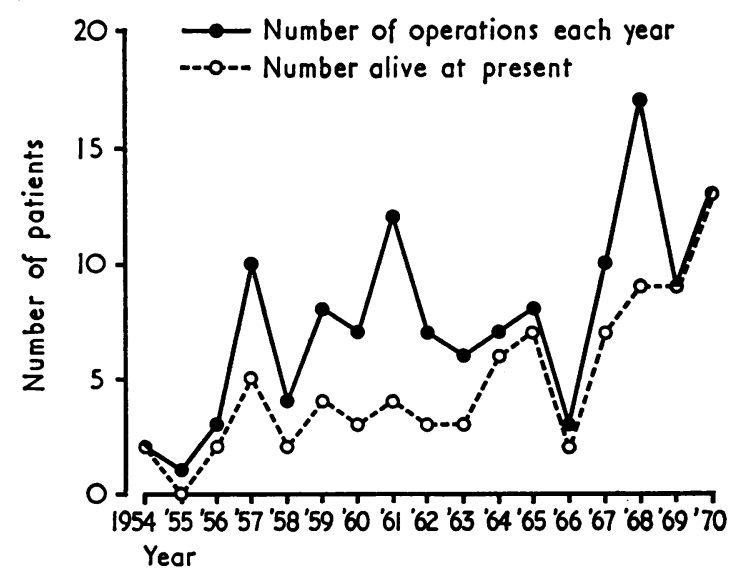

FIG. 2. Number of patients alive in December 1971 in relation to time since Blalock-Taussig shunt.

Figure 2 represents in graphic form the number of patients alive at the end of 1971 related to the year in which their Blalock-Taussig anastomosis was performed. The two patients operated on in 1954 were alive and well. Of the 12 operated on in 1961 only four were alive at the close of the study ; this was related to a transiently high surgical mortality associated with early experience in total correction as a second-stage procedure.

\section{DISCUSSION}

The $10 \%$ surgical mortality in our series was identical with that observed in previous reports (White, McNamara, Bauersfeld, and Taussig, 1956 ; Deuchar, Bescos, and Chakorn, 1972). The high mortality in infants was considered to be a reflection of the greater severity of the right ventricular outflow obstruction in those presenting early in urgent need of surgical relief.

Indeed this high mortality is largely an indication of failure to establish a large enough anasto- mosis between the small vessels presented at operation. In this context the introduction of an anastomosis between ascending aorta and right main pulmonary artery (Waterston, 1962) has provided for the infant a more adequate palliative shunt and this we employed in the latter part of our series.

Late complications were few, the commonest being cerebral abscess. Bacterial endocarditis, quite frequently encountered by Deuchar et al. (1972), was not proven in any of our patients, but it could not be entirely ruled out in five patients who died at home, three from an unknown cause and two in cardiac failure.

The apparent absence of pulmonary hypertension after the shunt operation was in keeping with the findings of Deuchar et al. (1972). The subclavian artery to pulmonary artery anastomosis carries a much lower risk of pulmonary hypertension than a direct anastomosis between aorta and pulmonary artery. The reason for this complication is an excessively large pulmonary blood flow (Paul, Miller, and Potts, 1961 ; McGaff, Ross, and Braunwald, 1962 ; Cole, Muster, Fixler, and Paul, 1971), and a practical consequence is that the timing of corrective surgery may become a matter of urgency when the anastomosis is between these major arteries (Bernuth et al., 1971).

Campbell (1972) estimated that the average life span in Fallot's tetralogy without operation was 15 years. The outlook has been improved both with the earlier palliative procedures and more recently with total correction. Taussig (1972) reported long-term survival in a patient who was well and active 24 years after a Blalock-Taussig anastomosis. The same author, analysing results in 500 patients who had undergone a BlalockTaussig anastomosis, found that after five years $67 \%$ had still maintained their improvement (White et al., 1956). Ten to 13 years after operation more than $40 \%$ were still well and active (Taussig, Crawford, Pelargonio, and Zachariou- 
dakis, 1962). Of 45 of our patients who had undergone their shunt operation three to nine years earlier $75 \%$ (34) were alive and well. Among 48 operated upon nine to 17 years before, $50 \%$ (24) were alive and well, although 13 had required a subsequent operation. These figures and those of Taussig show close similarity.

Total correction is now the treatment of choice, but the mortality remains in the region of $10 \%$ (Kirklin, Wallace, McGoon, and DuShane, 1965 ; Malm et al., 1966) and may be even greater in patients who have had a previous operation. More recent experience with improved techniques have produced better results (Goldman, Mustard, and Trusler, 1968). In certain very severe cases of right ventricular outflow tract obstruction, total correction may not be a practicable undertaking. In these circumstances either a Blalock-Taussig anastomosis or in infants a Waterston shunt (Waterston, 1962) can be relied upon to bring about a degree of improvement in symptoms maintained over several years. Our present policy is to avoid where possible the greater risks attached to a double operative procedure, palliative followed by radical, and to proceed directly to the latter. Where, however, the patient has had a shunt operation because of the early onset of acute symptoms we do not consider that radical surgical treatment is urgently needed unless there are increasing symptoms, a rising haematocrit, a disappearing shunt murmur, or an increasing incidence of cyanotic attacks. Where there is no urgency we recommend the corrective operation before the end of the first decade.

\section{REFERENCES}

Bernuth, G. von, Ritter, D. G., Frye, R. L., Weidman, W. H., Davis, G. D., and McGoon, D. C. (1971). Evaluation of patients with tetralogy of Fallot and Potts' anastomosis. Amer. J. Cardiol. 27, 259.

Blalock, A., and Taussig, H. B. (1945). The surgical treatment of malformations of the heart. J. Amer. med. Ass. 128, 189.
Brock, R. C. (1948) Pulmonary valvulotomy for the relief of congenital pulmonary stenosis. Brit. med.J., 1, 1121.

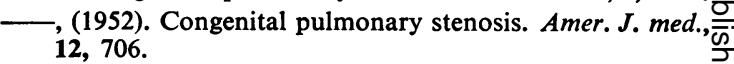

Campbell, M. (1972). Natural history of cyanotic mal- $\stackrel{\mathbb{Q}}{\varrho}$ formations and comparison of all common cardiaco malformations. Brit. Heart J., 34, 3.

Cole, R. B., Muster, A. J., Fixler, D. E., and Paul, M. H. $\vec{\circ}$ (1971). Long-term results of aortopulmonary anastomosis for tetralogy of Fallot. Morbidity and mortality, $\vec{\omega}$ 1946-1969. Circulation, 43, 263.

Deuchar, D., Bescos, L. L., and Chakorn, S. (1972). Fallot's tetralogy. A 20-year surgical follow-up. Brit. Heart J., î 34, 12.

Goldman, B. S., Mustard, W. T., and Trusler, G. S. (1968). Total correction of tetralogy of Fallot: review of ten years' experience. Brit. Heart J., 30, 563.

Kirklin, J. W., Wallace, R. B., McGoon, D. C., and DuShane, 을 J. W. (1965). Early and late results after intracardiac repair of tetralogy of Fallot. Five-year review of $337 \mathrm{Z}$ patients. Ann. Surg., 162, 578.

Malm, J. R., Blumenthal, S., Bowman, F. O., Ellis, $\mathrm{K}$ Jameson, A. G., Jesse, M. J., and Yeoh, C. B. (1966). Factors that modify hemodynamic results in total $\omega$ correction of tetralogy of Fallot. J. thorac. cardiovasc. Surg., 52, 502.

McGaff, C. J., Ross, R. S., and Braunwald, E. (1962). The development of elevated pulmonary vascular $\bar{O}$ resistance in man following increased pulmonary blood flow from systemic-pulmonary anastomoses. Amer. J. med., 33, 201.

Paul, M. H., Miller, R. A., and Potts, W. J. (1961). Long-ㅡㅡ term results of aortic-pulmonary anastomosis for 3 tetralogy of Fallot. Circulation, 23, 525.

Potts, W. J., Smith, S., and Gibson, S. (1946). Anastomosiso of the aorta to a pulmonary artery. Certain types in congenital heart disease. J. Amer. med. Ass., 132, 627.

Taussig, H. B., Crawford, H., Pelargonio, S., and Zacharioudakis, S. (1962). Ten to thirteen year follow-up $\times$ on patients after a Blalock-Taussig operation. Circu-O lation, 25, 630.

—_, (1972). 24-year follow-up on a patient with a Blalock-응 Taussig anastomosis at 23 months. Brit. Heart J., 34, 9.

Waterston, D. J. (1962). Treatment of Fallot's tetralogy in children under one year of age. Rozhl. Chir., 41, 181 .

White, B. D., McNamara, D. G., Bauersfeld, S. R., and至. Taussig, H. B. (1956). Five-year postoperative results of first 500 patients with Blalock-Taussig anastomosis. for pulmonary stenosis or atresia. Circulation, 14, 512. N 